\title{
Age determination of Acacia erioloba trees in the Kalahari
}

\author{
C.J. Steenkamp ${ }^{\mathrm{a}, 1}$, J.C. Vogel $^{\mathrm{b}}$, A. Fuls ${ }^{\mathrm{b}}$, N. van Rooyen ${ }^{\mathrm{a}}$ and M.W. van Rooyen ${ }^{\mathrm{a}}$ \\ ${ }^{a}$ Department of Botany, University of Pretoria, Pretoria 0002, South Africa \\ ${ }^{\mathrm{b}}$ Quaternary Dating Research Unit, Division of Water, Environment and Forest \\ Technology, CSIR, Pretoria 0002, South Africa
}

\section{Abstract}

High quality wood core samples were collected from individual Acacia erioloba trees of unknown age in the Kgalagadi Transfrontier Park. In the majority of samples examined, seasonal changes were reflected in the wood anatomy as bands of marginal parenchyma on the polished surfaces of discs or cores. Estimated radiocarbon age was determined by means of ${ }^{14} \mathrm{C}$ analysis for all samples. There was a strong correlation between the annual growth ring count and estimated radiocarbon age. A correlation was also found between age and stem circumference. Age structure of several $A$. erioloba populations in the Kgalagadi Transfrontier Park was subsequently determined. It could be demonstrated that the populations growing in the bed of the Nossob River showed poor recruitment; however, no clear relationship was found between flooding and regeneration of $A$. erioloba in the riverbed. The population growing in the dune field had a healthy age structure.

\section{Article Outline}

1. Introduction

2. Study area

3. Materials and methods

3.1. Sampling and sample preparation 
3.2. Anatomical study

3.3. Carbon dating

4. Results and discussion

4.1. Population structure

5. Conclusion

Acknowledgements

References

\section{Introduction}

Throughout most of the arid regions of the African continent, species of the genus Acacia are prominent components of the landscape. In the southern Kalahari, Acacia erioloba is regarded as a keystone species. It provides food, shade, shelter, perch, nest and roost sites to many animal species and harbours a distinct assemblage of plant species below its canopy (Leistner, 1967; Milton and Dean, 1995). The pods have a high nutritive value and constitute an important source of food for wild and domestic browsers (Barnes et al., 1997; Timberlake et al., 1999). In South Africa, A. erioloba has protected status because of its ecological importance, cultural value and because it is threatened by uncontrolled (illegal) harvesting for commercial firewood (Seymour and Milton, 2003). In 2001, it was estimated that up to 60 tons were being bundled on some properties (Anderson and Anderson, 2001; Liversidge, 2001). Land is also sometimes cleared of A. erioloba to improve pasture under the false belief that this species causes bush encroachment (Seymour and Milton, 2003).

Besides harvesting or other management actions, the population structure, density and distribution of A. erioloba is also determined by weather patterns (Jeltsch et al., 1996). Long-term monitoring data on the size structure of A. erioloba trees in the Nossob River in the Kgalagadi Transfrontier Park indicated a poor survival of seedlings and an almost complete lack of juvenile plants. This recruitment failure combined with the decline in isolated mature trees is changing the population structure of the species (Van Rooyen et al., 1996). The generation of patchiness, which is a keystone function of A. erioloba, is only performed by large trees, and a change in the population structure could therefore 
also alter the role of this species in the ecosystem (Dean et al., 1999; Milton and Dean, 1995).

Information on growth and age-size relationships is the basis for understanding population dynamics of long-lived plant species and is essential to manage populations whether the objectives are for the conservation of biodiversity or for agricultural production. If sustainable utilisation of a population is intended to prevent overexploitation and degradation of a resource, detailed information on actual growth rates is vital.

Reliable site-specific growth rates may be inferred from counts and measurements of annual growth rings in woody plants (Gourlay, 1995; Stahle et al., 1999; Worbes, 1995; Worbes et al., 2003). Dendrochronology has also been shown to be a useful tool for analysing demographic trends and reconstructing past climatic and streamflow patterns (Enquist and Leffler, 2001; Fichtler et al., 2004; Stahle et al., 1999). The estimation of tree ages by dendrochronology has not been widely applied in southern Africa for two reasons. Firstly, tree ring research in southern Africa appears to have been hampered by the general belief that species suitable for dendrochronological studies are lacking (Lilly, 1977). Secondly, the existence of tree rings in the tropical regions of southern Africa was disputed. The lack of distinct annual rings was attributed to the absence of low temperatures and an associated winter dormant season in most tropical climates. However, several recent studies have demonstrated that where pronounced seasonality of rainfall or seasonal flooding occurs (even in tropical regions), this climatic variation may be sufficient to induce an annual rhythm of radial growth to produce annual growth rings (Dezzeo et al., 2003; Enquist and Leffler, 2001; Fichtler et al., 2004; [Schoengart et al., 2002] and [Schoengart et al., 2004]; [Stahle et al. 1996] and [Stahle et al., 1999]; Trouet et al., 2001; [Worbes, 1995] and [Worbes, 1999]; Worbes et al., 2003) and that even in the ever-wet tropical rain forest, growth can have an annual periodicity (Fichtler et al., 2003). Detailed tree-ring studies of species in the savanna biome in southern Africa are very limited. Noteworthy studies are those of Fichtler et al. (2004) on Burkea africana and Pterocarpus angolensis in Namibia, Stahle et al. (1996) who screened 11 species for 
their dendrochronological potential in Zimbabwe and found three suitable species (Canthium burttii, Celtis africana and Vitex payos), and Stahle et al. (1999) and Therrell et al. (2007) on P. angolensis in southern Africa. Studies by Gourlay (1995) on Acacia species and Trouet et al. (2001) on miombo woodland species were conducted elsewhere on the African continent.

The objectives of this pilot study were (a) to investigate the use of tree ring counts to determine the age of $A$. erioloba trees, (b) to validate the ring count ages by radiocarbon dating and (c) to develop age-size relationships for A. erioloba. This age-size relationship is then applied to data from the Kgalagadi Transfrontier Park to analyse the population structure of this species in different habitats and under different intensities of use by ungulates. An important use of the age-size relationship is to investigate the possibility that the successful establishment of cohorts of A. erioloba in the Nossob Riverbed is dependent on rare flooding events.

\section{Study area}

The study was conducted in the Kgalagadi Transfrontier Park (Fig. 1), the South African part of which was formerly known as the Kalahari Gemsbok National Park (KGNP). The KGNP covers approximately $9600 \mathrm{~km}^{2}$ and is situated in the southwestern corner of the Kalahari between $24^{\circ} 15^{\prime} \mathrm{S}$ and $26^{\circ} 30^{\prime} \mathrm{S}$ and $20^{\circ} 00^{\prime} \mathrm{E}$ and $20^{\circ} 45^{\prime} \mathrm{E}$. The park is highly suitable for vegetation studies as it is representative of the entire southern Kalahari and the vegetation, being protected from overutilisation, is in good condition. 


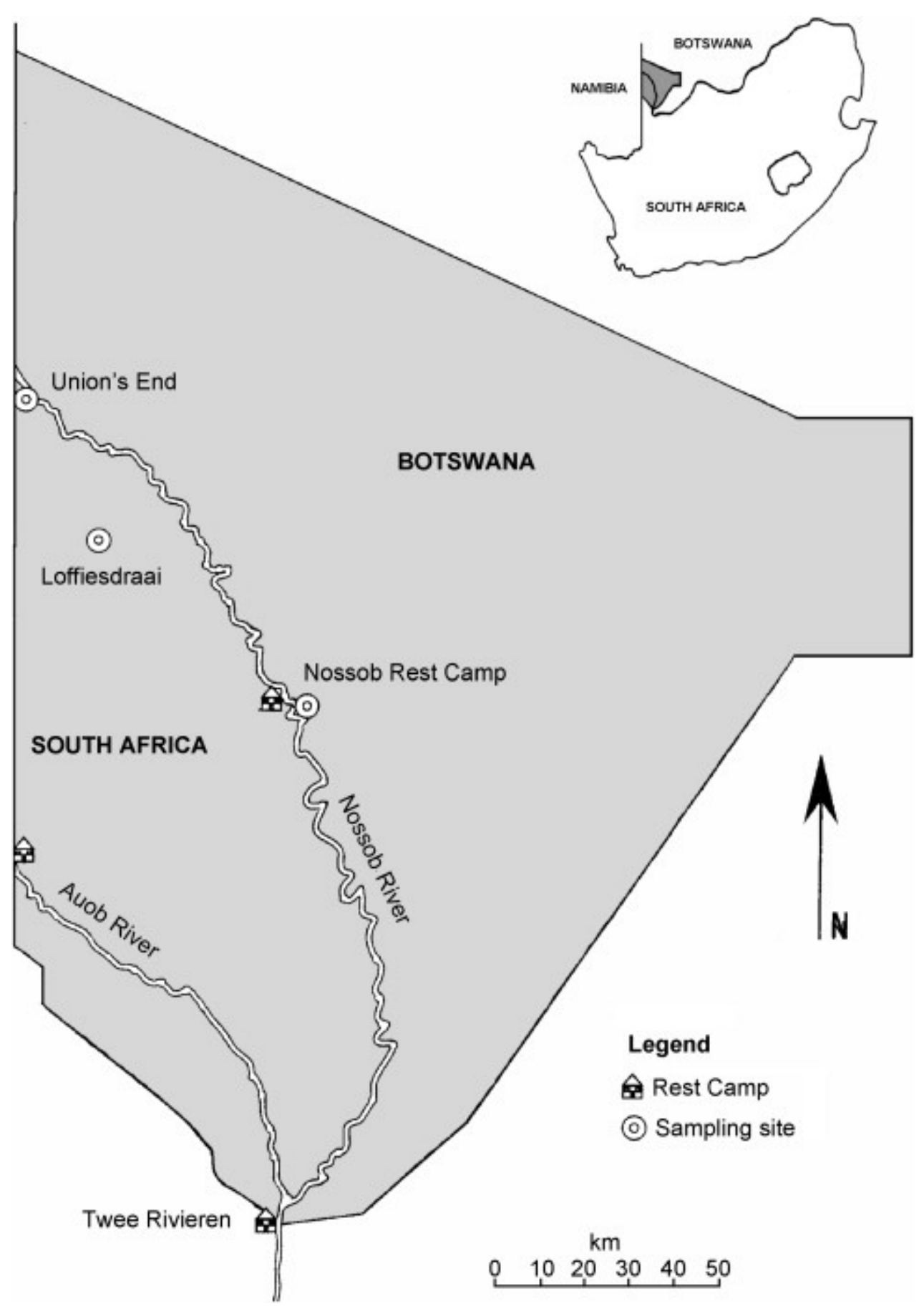

Fig. 1. Location of the study sites within the Kgalagadi Transfrontier Park (shaded area). The climate of the southern Kalahari can be described as temperate and arid. The mean annual rainfall ranges from 200 to $250 \mathrm{~mm}$ per annum and is unreliable and irregular, a feature that is of great significance to the vegetation of the Kalahari (Leistner, 1967; Van Rooyen and Van Rooyen, 1998). The highest rainfall occurs in the summer months, January-April, and there is a pronounced dry period lasting 4-6 months. Large 
temperature fluctuations, both on a daily and seasonal basis, are characteristic of the climate. Mean daily maximum and minimum temperatures are 34.7 and $19.5^{\circ} \mathrm{C}$, respectively, in January and 22.2 and $1.2^{\circ} \mathrm{C}$, respectively, in July (Weather Bureau, 1998) but summer highs can reach up to $45.4^{\circ} \mathrm{C}$ and winter lows to $-10.3^{\circ} \mathrm{C}$ (Van Rooyen et al., 1990).

\section{Materials and methods}

\subsection{Sampling and sample preparation}

Samples were collected in 1998 from 19 selected A. erioloba trees of differing stem circumference in two different habitats. The first habitat was the dry riverbed of the Nossob River at Union's End and Nossob Rest Camp and the other, the dune field $22 \mathrm{~km}$ west of the river at Loffiesdraai (Fig. 1).

Core sampling of indigenous hardwood species is not a common practice. A unique and effective non-destructive method of sampling was developed whereby high quality cores, suitable for radiocarbon dating and dendrochronological studies, could be obtained without permanently damaging trees (Steenkamp et al., 1999). Large specimens were sampled with this corer and permission was granted by SANParks to fell the smaller trees in order to obtain a complete disc for study. Samples were taken at a height of approximately $300 \mathrm{~mm}$ above ground level, the stem of this species being quite regular from the base. A belt sander was used to smooth the wood surfaces of the cores, starting with a coarse grit (60 grain) and working down to the finest available (1200 grain). The final polishing ensured that fine scratches could not be confused with marginal parenchyma.

\subsection{Anatomical study}

Tree rings are generally induced by seasonal variations in temperature and soil water. These stress factors interrupt cambial activity and a morphologically distinct xylem layer is produced which results in a discontinuity between annual growth increments (Enquist and Leffler, 2001). In the wood of A. erioloba, growth zones are separated by marginal parenchyma bands. Marginal parenchyma is a form of axial parenchyma produced by 
some trees at the end or beginning of a growth season. These bands are commonly composed of less than five rows of small parenchyma cells (Fig. 2), forming a continuous layer visible on the transverse surface as a fine light-coloured band ([Gourlay, 1992] and [Gourlay, 1995]).

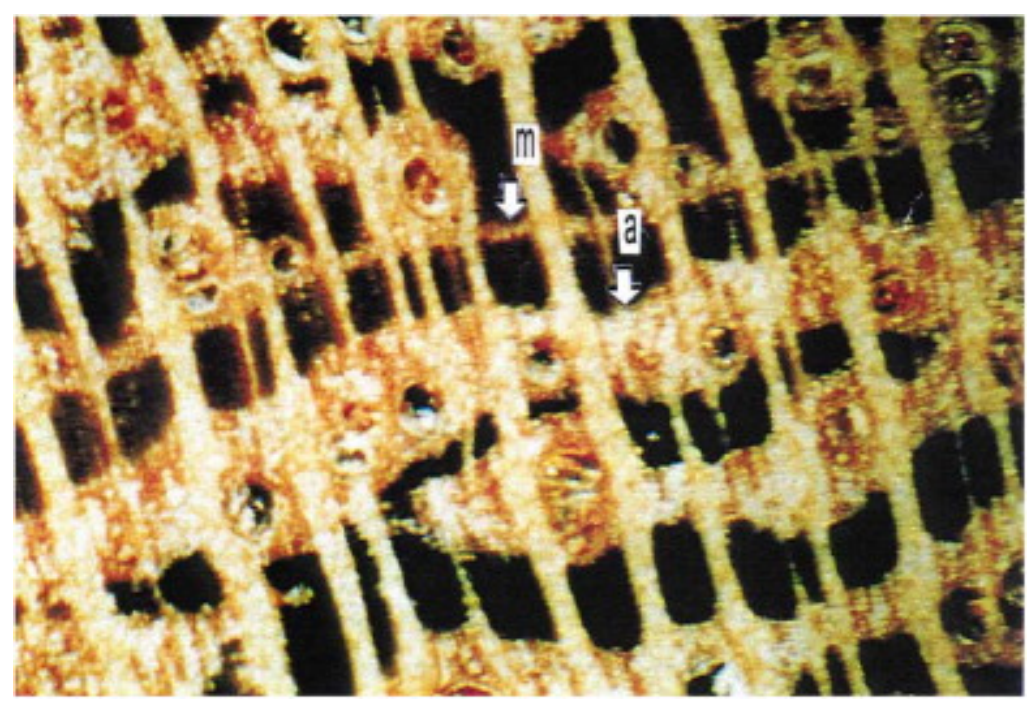

Fig. 2. Transverse section of aliform parenchyma (a) and marginal parenchyma (m); 10× magnification.

Sample discs and cores were viewed under a dissection microscope at $4 \times$ magnification. The marginal parenchyma rings were identified on the three best radii through the leastdisturbed sectors and then marked. Wedging rings occur in this species and therefore the final ring count was determined by taking the highest count on any of the radii. This value could still be an underestimate because the possibility cannot be excluded that wedging rings are still present in a core. In samples with a rotten core, accurate ages could not be determined by ring counts. In these cases, growth zones were measured and growth rates (mm per annum) calculated. Assuming uniform growth, the total number of rings was estimated by extrapolation. 


\subsection{Carbon dating}

In principle, the age of a tree can be determined with radiocarbon by analysing the innermost annual rings of the bole which formed when the plant started growing. The dating is, however, complicated. Especially for specimens between 50 and 350 years old, because the radiocarbon level of the environment during this period was not stable but showed substantial fluctuations (Stuiver et al., 1998; Worbes, 2002).

The relationship between the age and the relative radiocarbon level in the atmosphere and vegetation is shown in Fig. 3. It can be seen that the radiocarbon content of a sample does, in general, not correspond to a unique date in the past. If, for instance, a radiocarbon value of $97.5 \mathrm{pmC}$ (percent modern Carbon) is measured, the sample may date to either 1678,1758 or 1803 (Fig. 3). The correct age can only be deduced by measuring several samples with increasing distance from the core and fitting the results to the calibration curve (Vogel and Fuls, 2005; Vogel et al., 2001).

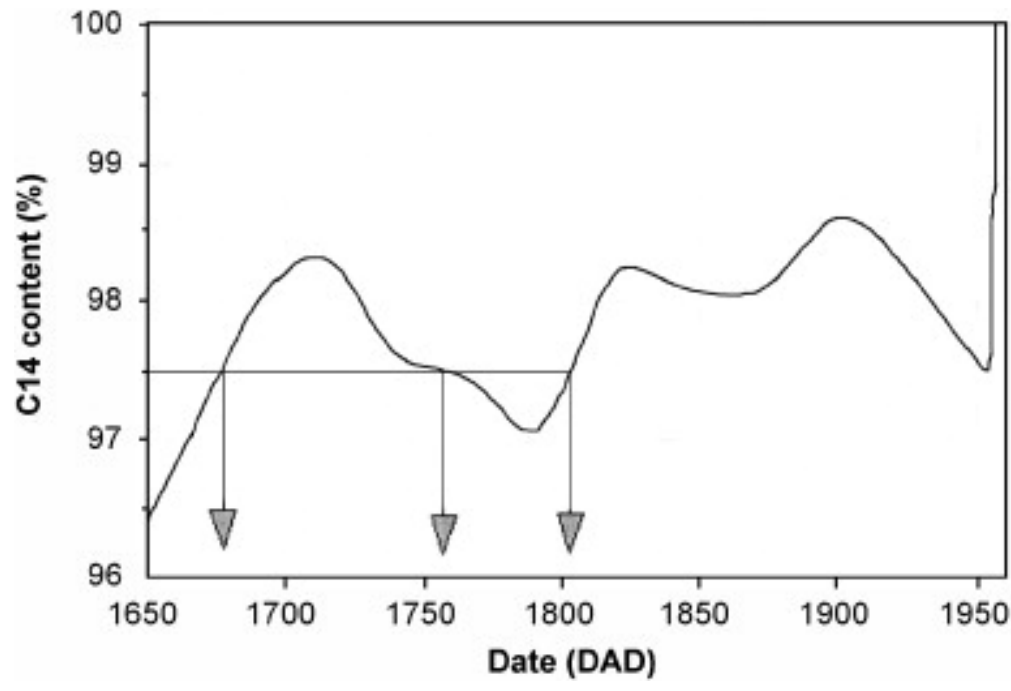

Fig. 3. Calibration curve for ${ }^{14} \mathrm{C}$ age in years for the southern hemisphere.

The nuclear fusion bomb explosions that were conducted between 1954 and 1962 introduced a large amount of artificially produced radioactive isotopes into the atmosphere and by 1965, the level of radiocarbon in the southern hemisphere had risen to $65 \%$ above normal, i.e. to $165 \mathrm{pmC}$. After the suspension of atmospheric tests in the 
atmosphere, the excess radiocarbon gradually declined. The development as measured in Pretoria is shown in Fig. 4. The Pretoria calibration curve used here is derived from the recommended curve, INTCAL 98 (Stuiver et al., 1998), appropriately adjusted to the Southern Hemisphere (Vogel, 2000; Vogel et al., 1993). Samples with above normal radiocarbon levels (i.e. $>100 \mathrm{pmC}$ ) can, in general, be allocated to two different dates and, here again, additional information is required to arrive at the correct age (Vogel et al., 2002; Worbes and Junk, 1989). Due to the rapid change in the level during this period, the dating is accurate to \pm 2 years, while for older samples, the uncertainty is of the order of decades.

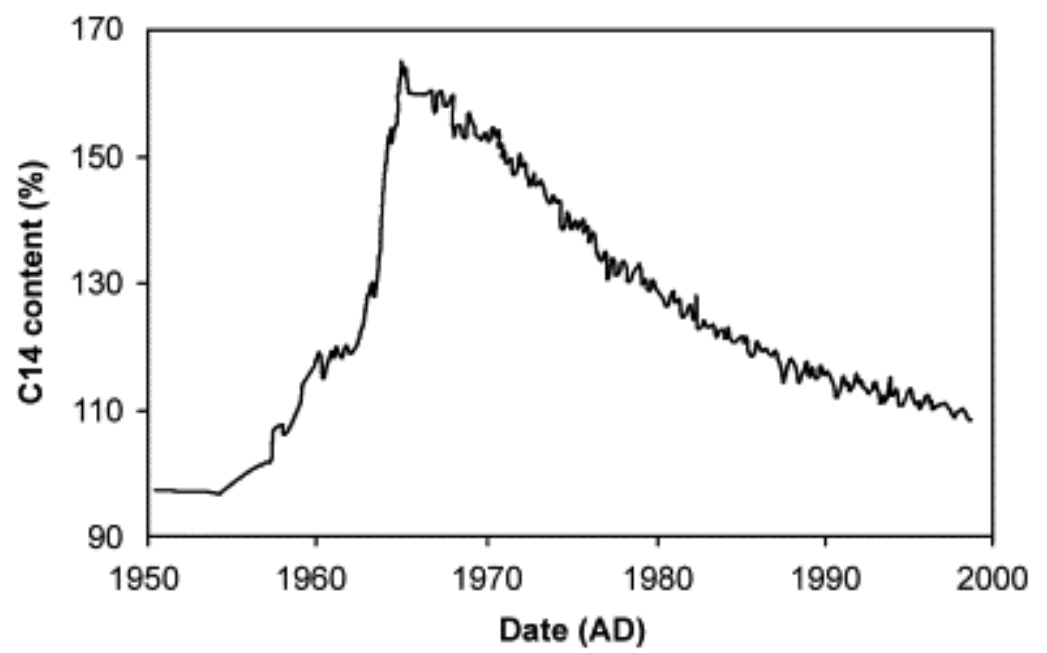

Fig. $4 .{ }^{14} \mathrm{C}$ content of atmospheric carbon dioxide in recent years, expressed in per mille above normal (extended after Vogel, 1971; Vogel et al., 1993).

Initially, the centre of each core or disc was analysed. The material was purified with acid and alkali, using standard procedures and in some cases, pure cellulose was prepared. The results were corrected for variations in isotope fractionation with the aid of ${ }^{13} \mathrm{C}$ analyses (Vogel et al., 1986). Where the analysis indicated two or more possible dates, a second sample between the core and the bark was processed in an attempt to identify the correct age. A linear growth rate was assumed for extrapolating the age of the outer samples to the core. 


\section{Results and discussion}

Growth rings of $A$. erioloba were visible in the wood anatomy as bands of marginal parenchyma (Fig. 2). The marginal parenchyma bands can usually be distinguished from the frequent intra-seasonal banded parenchyma by their fineness, by more irregular spacing between the broader bands and by evenness of appearance in contrast to the more irregular, wavy, confluent bands. The broad bands of aliform-confluent parenchyma often mask the finer marginal bands, and sometimes completely obscure them. Further complications were experienced in the form of wedging or partial rings and the presence in several samples of dense, dark, heartwood, often filled with gum deposits. This demanded diligently following the growth zone around the circumference.

The unfavourable growing period in the southern Kalahari is characterised by both drought and low temperatures. The phenology of $A$. erioloba is synchronised with this seasonality and a brief leafless period occurs in late winter (Smit, 1999). Because cambial activity is generally induced by flushing and terminated some time before leaf shedding (Borchert, 1999), the growth patterns in the wood of this species are probably annual. Results of the carbon dating supported this assumption and rings were consequently regarded as annual rings.

Details of the radiocarbon analyses and the ages deduced for the sampled trees are given in Table 1 together with the ring counts. Several of the samples at or near the core of the bole produced values between 99 and 100 pmC (Table 1, column 4), which suggests a date of 1955. On the basis of the result for the second sample closer to the bark, this dating was often unacceptable. The reason for these discrepancies could be that the decayed and porous core samples were contaminated with organic matter of a postnuclear bomb age, introduced, for instance, by termites. Dead termites were indeed found in the core of the trunk of UE21 and signs of termite activity were seen in LD9. 


\section{Table 1.}

Estimated age of Acacia erioloba samples by carbon dating and ring counts

\begin{tabular}{|c|c|c|c|c|c|c|c|c|c|}
\hline 1 & 2 & 3 & 4 & 5 & 6 & 7 & 8 & 9 & 10 \\
\hline $\begin{array}{l}\text { Sample } \\
\text { no. }\end{array}$ & $\begin{array}{l}\text { Stem } \\
\text { circumference } \\
(\mathrm{cm})\end{array}$ & $\begin{array}{l}\text { Location of sample } \\
\text { for carbon analysis } \\
\text { (cm) from outside }\end{array}$ & $\begin{array}{l}{ }^{14} \mathrm{C} \\
\text { content } \\
\text { (pmC) }\end{array}$ & $\begin{array}{l}\text { Error } \\
(\mathrm{pmC})^{\mathrm{a}}\end{array}$ & $\begin{array}{l}\text { Estimated age } \\
\text { of tree (years) }\end{array}$ & $\begin{array}{l}\text { Also } \\
\text { possible age } \\
\text { (years) }\end{array}$ & $\begin{array}{l}\text { Ring } \\
\text { count }\end{array}$ & Comments & $\begin{array}{l}\text { Average radial } \\
\text { growth rate } \\
\text { (cm/year) }\end{array}$ \\
\hline LD1 & 79 & $11.3-8.8$ & 98.62 & 0.33 & 55 & 112 & 46 & & 0.21 \\
\hline LD2 & 43 & $6.0-5.0$ & 100.17 & 0.59 & 44 & & 34 & $\begin{array}{l}\text { Wedging rings, } \\
\text { scarred tissue }\end{array}$ & 0.14 \\
\hline LD3 & 29 & $3.5-2.5$ & 126.00 & 0.64 & $18^{\mathbf{b}}$ & 46 & 18 & & 0.19 \\
\hline LD4 & 35 & $4.5-3.5$ & 133.03 & 0.65 & $24^{\mathrm{b}}$ & 42 & 28 & & 0.19 \\
\hline LD5 & 52 & $7.3-6.3$ & 100.83 & 0.26 & 45 & & 42 & & 0.16 \\
\hline LD6 & 14 & $1.7-0.7$ & 119.06 & 0.65 & $15^{b}$ & 80 & & & 0.11 \\
\hline LD7 & 78 & $11.3-10.3$ & 118.39 & 0.25 & 50 & 12 & 39 & Wedging rings & 0.23 \\
\hline LD8 & 20 & $2.5-1.5$ & 123.69 & 0.68 & $17^{\mathbf{b}}$ & 55 & & & 0.15 \\
\hline \multirow[t]{2}{*}{ LD9 } & 98 & $14.5-12.5$ & 99.67 & 0.31 & $210^{c}$ & & $130+^{d}$ & $\begin{array}{l}\text { Decayed core, } \\
\text { termites }\end{array}$ & 0.07 \\
\hline & & $3.5-2.5$ & 98.49 & 0.34 & & & & & \\
\hline LD10 & 97 & $10.5-9.5$ & 98.74 & 0.25 & 62 & 132 & $57^{d}$ & $\begin{array}{l}\text { Decayed core, } \\
\text { wedging rings }\end{array}$ & 0.22 \\
\hline \multirow[t]{2}{*}{ LD11 } & 147 & $18.0-17.0$ & 99.33 & 0.32 & $197^{c}$ & & $130^{d}$ & $\begin{array}{l}\text { Decayed core, } \\
\text { wedging rings }\end{array}$ & 0.12 \\
\hline & & $6.2-4.8$ & 100.04 & 0.56 & & & & & \\
\hline LD12 & 130 & $15.0-14.0$ & 99.76 & 0.58 & 100 & 45 & & & 0.15 \\
\hline
\end{tabular}




\begin{tabular}{|c|c|c|c|c|c|c|c|c|c|}
\hline 1 & 2 & 3 & 4 & 5 & 6 & 7 & 8 & 9 & 10 \\
\hline $\begin{array}{l}\text { Sample } \\
\text { no. }\end{array}$ & $\begin{array}{l}\text { Stem } \\
\text { circumference } \\
(\mathrm{cm})\end{array}$ & $\begin{array}{l}\text { Location of sample } \\
\text { for carbon analysis } \\
\text { (cm) from outside }\end{array}$ & $\begin{array}{l}{ }^{14} \mathrm{C} \\
\text { content } \\
\text { (pmC) }\end{array}$ & $\begin{array}{l}\text { Error } \\
(\mathrm{pmC})^{\underline{a}}\end{array}$ & $\begin{array}{l}\text { Estimated age } \\
\text { of tree (years) }\end{array}$ & $\begin{array}{l}\text { Also } \\
\text { possible age } \\
\text { (years) }\end{array}$ & $\begin{array}{l}\text { Ring } \\
\text { count }\end{array}$ & Comments & $\begin{array}{l}\text { Average radial } \\
\text { growth rate } \\
\text { (cm/year) }\end{array}$ \\
\hline \multirow[t]{3}{*}{ LD14 } & 170 & $18.0-17.0$ & 97.39 & 0.25 & $128^{c}$ & 204 & $90^{d}$ & $\begin{array}{l}\text { Very porous, } \\
\text { decayed core }\end{array}$ & 0.14 \\
\hline & & $17.0-16.0$ & 97.76 & 0.60 & & & & & \\
\hline & & $6.4-4.9$ & 106.43 & 0.47 & & & & & \\
\hline UE16 & 8 & $0.8-0$ & 113.00 & 0.64 & $6^{\mathrm{b}}$ & & 3 & & 0.13 \\
\hline \multirow[t]{2}{*}{ UE20 } & 200 & $31.0-28.0$ & 99.66 & 0.26 & 126 & & & Very porous & 0.24 \\
\hline & & $10.1-9.5$ & 109.28 & 0.50 & & & & & \\
\hline \multirow[t]{2}{*}{ UE21 } & 50 & $7.5-4.5$ & 98.27 & 0.25 & 60 & 140 & 51 & $\begin{array}{l}\text { Porous, } \\
\text { termites }\end{array}$ & 0.13 \\
\hline & & $7.5-4.5$ & 99.46 & 0.57 & & & & & \\
\hline UE22 & 69 & $8.0-7.0$ & 99.08 & 0.48 & 46 & 102 & 44 & & 0.17 \\
\hline \multirow[t]{2}{*}{$\mathrm{NC} 24$} & 118 & $13.8-11.8$ & 95.53 & 0.33 & 82 & & $53+^{d}$ & Decayed core & 0.17 \\
\hline & & $8.0-6.7$ & 101.45 & 0.26 & & & & & \\
\hline $\mathrm{NC} 25$ & 134 & $19.0-17.0$ & 157.31 & 0.32 & $36^{\mathbf{b}}$ & 32 & 34 & & 0.53 \\
\hline
\end{tabular}

$\mathrm{LD}=$ Loffiesdraai; UE=Unie End; $\mathrm{NC}=$ Nossob Camp.

${ }^{\mathrm{a}}$ Error (pmC) refers to the $1 \sigma$ sigma uncertainty of the actual measurement.

${ }^{\mathrm{b}}$ These specimens show post nuclear ${ }^{14} \mathrm{C}$ and are accurate to \pm 2 years. The ages of the rest are much less precise.

${ }^{\mathrm{c}}$ The age is based on extrapolation assuming linear growth.

${ }^{\mathrm{d}}$ Not all rings could be counted and the age is extrapolated assuming linear growth estimated from the counted rings. 
The ages derived by radiocarbon analyses are given in column 6 of Table 1, and where another age cannot be excluded on the basis of the result for the second sample, this age is listed in column 7. In Fig. 5, the radiocarbon ages for samples without rotten cores are compared with the annual ring counts from column 8 . The diamond markers represent the ages in column 6 and these show a highly significant correlation with the ring counts $\left(r^{2}=0.93\right)$ so that the alternate ages in column 7 (squares) can confidently be rejected. This illustrates that ring counting can effectively be used to eliminate alternate ages where more than one date is possible. However, the age estimates based on the marginal parenchyma rings are lower than the radiocarbon ages, indicating that on average only $89 \%$ of the annual rings could be recognised.

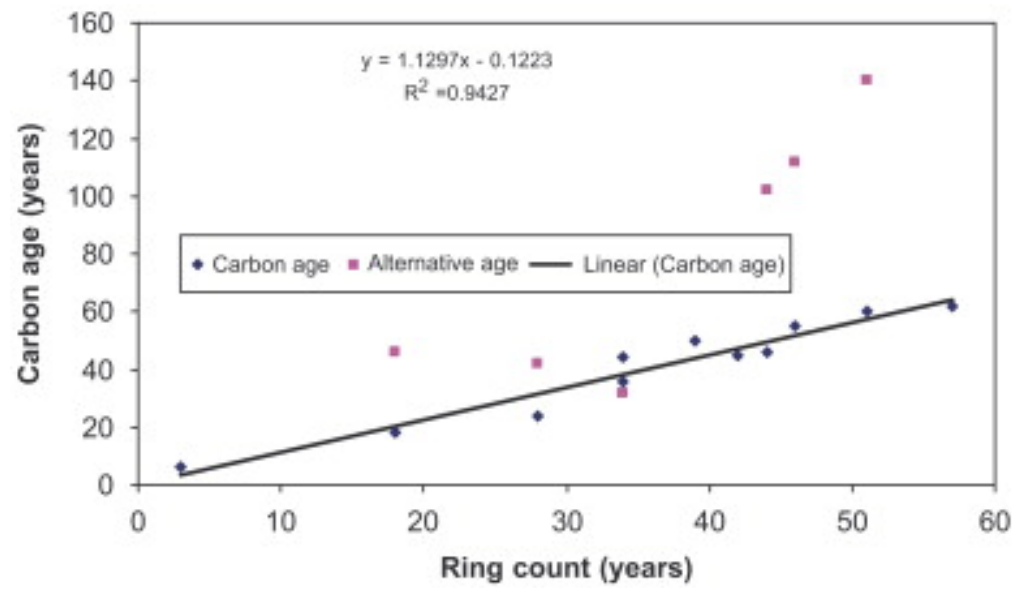

Fig. 5. Relationship between radiocarbon age and the ring counts. Diamond markers represent the most probable age; square markers represent alternative ages.

The mean annual radial growth rates, based on the selected ages in column 6 are listed in column 10. The mean for the whole set is $1.8 \mathrm{~mm} /$ year (corresponding to an annual diameter increment of $3.6 \mathrm{~mm} /$ year), which is lower than the value of 6-7 mm/year (annual diameter increment of 12-14 mm) previously reported for Acacia species growing in arid and semi-arid environments (Gourlay, 1992), but compares well to the diameter increase of 3-4 mm/year for P. angolensis (Stahle et al., 1999; Therrell et al., 2007). 
In Fig. 6, the radiocarbon ages are plotted against the measured circumferences of the trunks (Table 1, column 2). Those specimens with rotten cores where the age could only be estimated by extrapolation were omitted. Here again, the ages in column 6 show a significant correlation $\left(r^{2}=0.74\right.$, intercept forced through zero) with the size of the boles, albeit with one exception ( $\mathrm{NC25}$ ). The dating of $\mathrm{NC} 25$, with its exceptionally broad ring structure, is secure. This tree was standing on the edge of the watercourse and was probably experiencing very favourable conditions. Stahle et al. (1996) reported similar variability in the growth rate of $P$. angolensis in Zimbabwe and suggested differences in microsite conditions and/or genetic potential of individual trees as underlying cause. It is notable that there was no observable difference in size-age relationships of trees from the dry riverbed and those growing in the waterless savanna at Loffiesdraai. The annual growth rate derived from this equation $(2.53 \mathrm{~mm}$ annual radial increment or $5.06 \mathrm{~mm}$ annual diameter increment) is higher than the mean derived from the carbon dating.

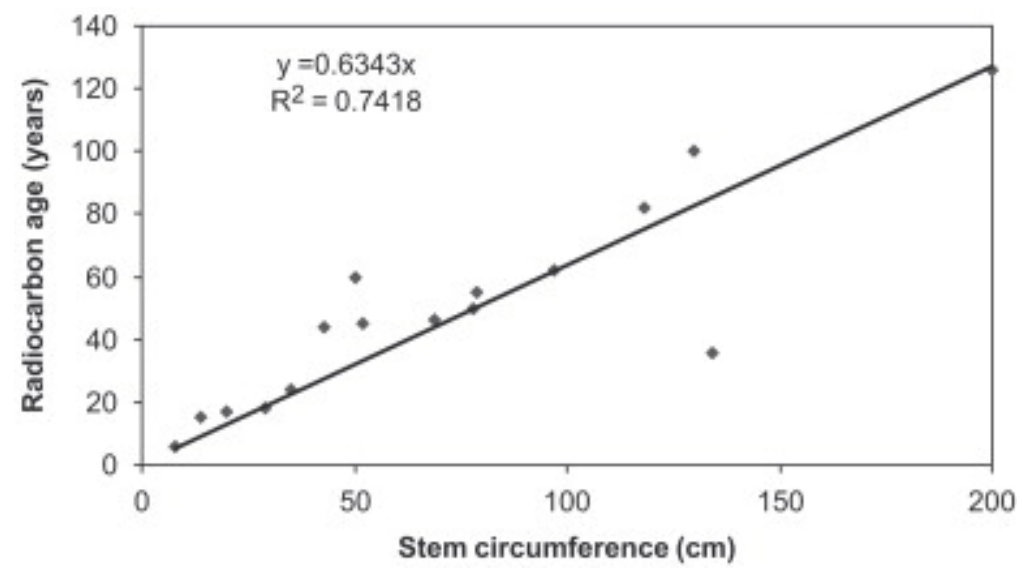

Fig. 6. The relationship between stem circumference and estimated age of Acacia erioloba by radiocarbon dating.

\subsection{Population structure}

Stem circumferences of $A$. erioloba trees growing in the Nossob Riverbed as well as the dune field at Loffiesdraai were recorded in 1994. The linear regression derived from the data in Fig. 6 was used to evaluate the actual age structure of these populations. The age distribution clearly shows an unhealthy population with poor recruitment in the riverbed 
(Fig. 7a and b), while there is an unusually high frequency of young trees in the dunes (Fig. 7c).

a

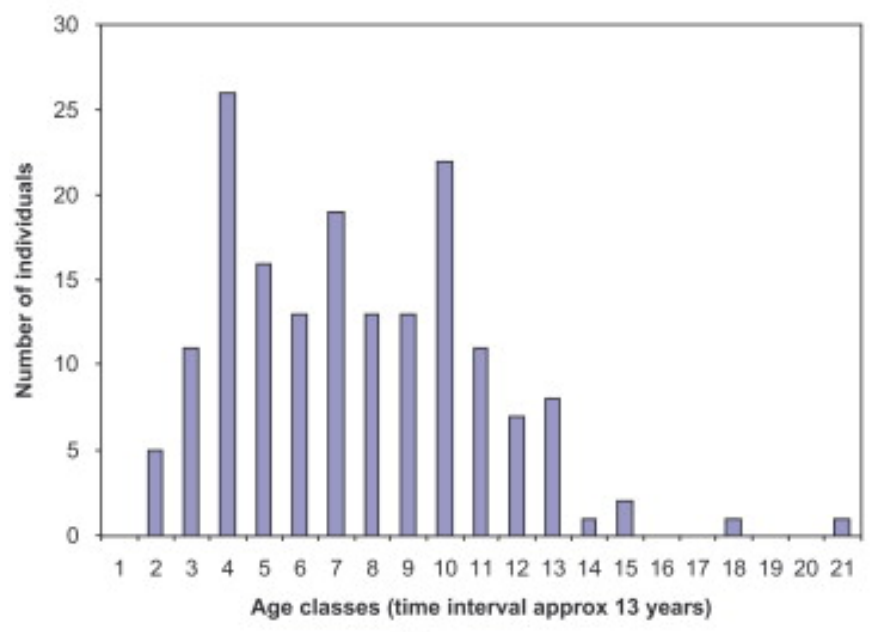

C b

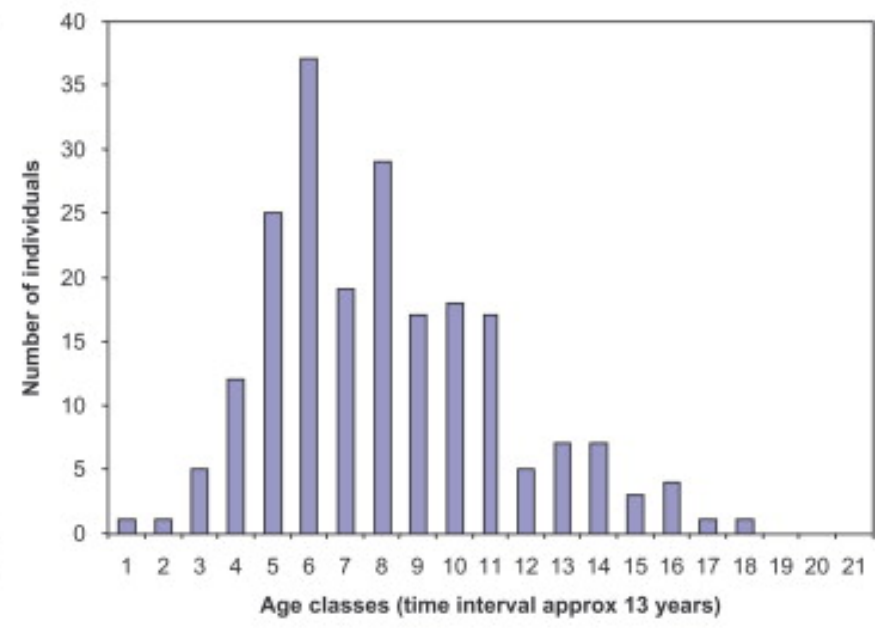

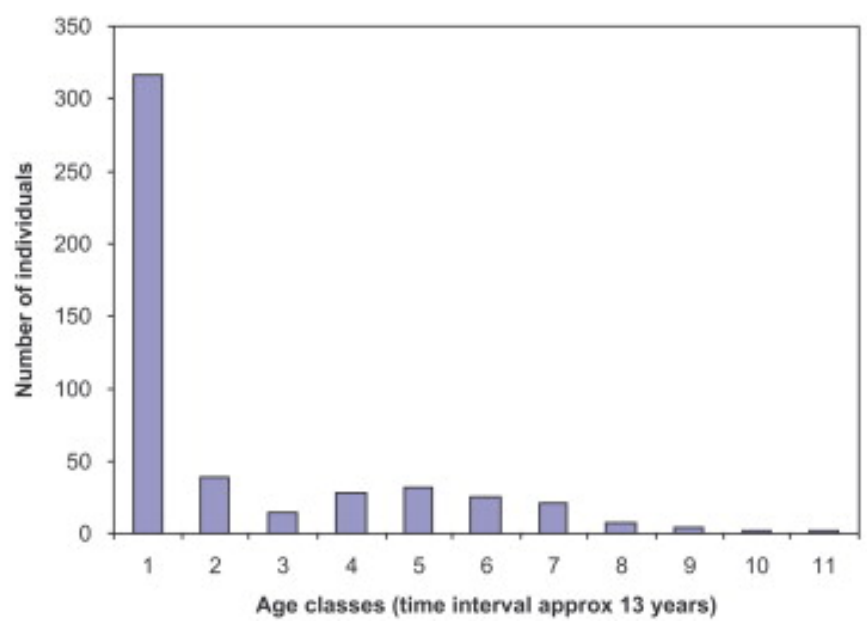

Fig. 7. Age structure of Acacia erioloba populations using the age-size regression: (a) away from the watering point, (b) at the watering point and (c) in the dune field. The major determinants of vegetation dynamics in the Kalahari are the timing and amount of seasonal rainfall, the existence of relatively long-term rainfall/drought cycles (ca. 10-20 years) and the occurrence of sporadic flooding (Van Rooyen et al., 1996). Although floods are rare, they are important in that they sustain the relatively high water table of the rivers (Leistner, 1967), lead to local accumulation of tree seeds (Jeltsch et al., 1996; Ward and Breen, 1983), favourable conditions for germination and increase establishment probabilities (Van Rooyen et al., 1996). 
It has been suggested that the regeneration of A. erioloba in the Nossob River depends on the sporadic flooding of the river and/or consecutive years of above-average rainfall. One of the reasons for the poor recruitment of the populations in the Nossob River could therefore be that impoundments in the upper reaches of the river in Namibia prevent floodwaters from reaching the Kgalagadi Transfrontier Park. The age structure of the Nossob River populations was examined to determine whether there was any relationship between successful recruitment and previous flooding events. The last two times floods occurred in the northern Nossob River were in 1934 and 1963. These events (60 and 31 years prior to the 1994 survey) coincide with the third (25-38 years) and fifth (51-63 years) age classes in Fig. 7. However, the populations sampled between watering points showed a peak in the fourth and seventh age classes, while the populations sampled at watering points peaked in the sixth and eighth age classes. It therefore appears unlikely that these cohorts were recruited as a result of the 1934 or 1963 floods and the absence of flooding cannot satisfactorily explain the shortage of young individuals.

Because the precipitation in arid regions not only varies significantly from year to year, but is also highly localised, regeneration and survival may differ dramatically from place to place. Thus, while the overall annual precipitation in the region is approximately $200 \mathrm{~mm}, 565.3 \mathrm{~mm}$ was recorded at Union's End in 1988 and the next 3 years received 279.9, 245 and $318.6 \mathrm{~mm}$, respectively. In the same years, the Nossob Rest Camp, $130 \mathrm{~km}$ downstream recorded only 367, 133.3, 88.2 and $114.4 \mathrm{~mm}$ annually. The high presence of saplings at Loffiesdraai in the dunes, $50 \mathrm{~km}$ south of Union's End, could thus be the result of good local rains in the years 1988-1991. However, it would have been expected that these good rains would also have produced large numbers of saplings in the riverbed at Union's End, which was not the case. The large number of juvenile trees at Loffiesdraai could be the result of trees resprouting after a relatively recent fire. In general, mortality rates during seed germination and seedling establishment are much higher than during the adult stages (Brubaker, 1986). Seed germination is best after good rainfall events, and seedling survival depends on the availability of moisture during the next few seasons. As a result, recruitment is pulsed as evidenced by the presence of cohorts (Barnes, 2001; Ernst et al., 1990 and compare Fig. 7a and b). In dry years, 
seedlings and saplings of A. erioloba suffer high mortality rates (Barnes, 2001; Theron et al., 1985; Van Rooyen and Van Rooyen, 1998; Van Rooyen et al., 1984).

The concentration of wildlife in the riverbed could also have contributed towards the scarcity of young trees in the Nossob River. This is borne out by the fact that the population at the watering trough had even less young individuals than the population further away from the watering point. Losses may be due to trampling or herbivores that browse on the leaves of saplings.

Survival of seedlings depends on numerous environmental factors, such as amount and distribution of rainfall, grass competition and population levels of predatory insects and rodents. These factors need to be favourable and coincide with the presence of scarified seeds for successful stand establishment of seedlings. Although seeds readily germinate and seedlings may establish in their first year, this does not guarantee survival during the following 3-4 critical years of growth. In the river habitat, tree seedlings are also likely to encounter more competition from a well-developed grass layer than in the dune habitat. Likewise, insects and rodents may be more numerous in the river habitat and may have a greater negative impact on the size of the seed pool in the river habitat.

The increase in large, dead A. erioloba trees in the northern Nossob River could possibly be ascribed to fire. In arid regions, fires do not occur regularly because fuel loads are often not sufficient to carry a fire. However, after good rainfall, enough fuel accumulates to carry a fire. In general, only about one-third of the A. erioloba individuals are killed by fire, with most individuals resprouting again from the base. Old, large trees, especially those with hollow stems, are most sensitive to fire. These large trees are often home to tree rats and sociable weavers that accumulate dry material in the tree canopy. If this dry material is set alight, the chances that the tree will survive are slim. The keystone function of A. erioloba in the ecosystem is centred around the large trees and these large individuals are crucial for the maintenance of patterns and processes in the ecosystem (Milton and Dean, 1995). 


\section{Conclusion}

This study in a conservation area has provided an effective and rapid way to analyse the age structure of $A$. erioloba in the southern Kalahari. It was demonstrated that marginal parenchyma bands, demarcating annual growth periods, could be distinguished on polished wood discs and cores. A good correlation between radiocarbon dating and annual ring counts was found, although the annual ring count consistently underestimated the actual age of the tree by approximately 11\%. Furthermore, the study showed how tree rings could assist in radiocarbon dating of material less than 300 years old. Radiocarbon dating of such material usually produces two or more possible ages. Comparisons with annual ring counts indicate which of these possible ages is most likely to be the correct one. Using ring counts to confirm the possible age is considerably cheaper than carbon dating a second sample between the core and the bark.

The good correlation obtained between actual radiocarbon age and stem circumference allows this regression to be used to analyse the age structure of the population. It was found that growth rate did not differ significantly between trees growing in the Nossob Riverbed and trees growing in the dune field savanna. The populations sampled in the riverbed showed an unhealthy age structure with poor recruitment, however, no clear relationship was found between flooding and regeneration of $A$. erioloba in the riverbed. The dune population showed an abundance of small individuals, which could have been the result of resprouting after fire.

\section{References}

Anderson and Anderson, 2001 M.D. Anderson and T.A. Anderson, Too much, too quickly? Doubts about the sustainability of the camelthorn wood harvest, African Wildlife 55 (2001), pp. 21-23.

Barnes, 2001 M.E. Barnes, Seed predation, germination and seedling establishment of Acacia erioloba in northern Botswana, Journal of Arid Environments 49 (2001), pp. 541554. 
Barnes et al., 1997 R.D. Barnes, C.W. Fagg and S.J. Milton, Acacia erioloba: monograph and annotated bibliography, Oxford Forestry Institute Tropical Forestry Paper 35 (1997), pp. 1-66.

Borchert, 1999 R. Borchert, Climatic periodicity, phenology and cambium activity in tropical dry forest trees, IAWA Journal 20 (1999), pp. 239-247.

Brubaker, 1986 L.B. Brubaker, Responses of tree populations to climatic change, Vegetatio 67 (1986), pp. 119-130.

Dean et al., 1999 W.R.J. Dean, S.J. Milton and F. Jeltsch, Large trees, fertile islands, and birds in arid savanna, Journal of Arid Environments 41 (1999), pp. 61-78.

Dezzeo et al., 2003 N. Dezzeo, M. Worbes, I. Ishii and R. Herrera, Annual tree rings revealed by radiocarbon dating in seasonally flooded forest of the Mapire River, a tributary of the lower Orinoco River, Venezuela, Plant Ecology 168 (2003), pp. 165-175.

Enquist and Leffler, 2001 B.J. Enquist and J. Leffler, Long-term tree ring chronologies from sympatric tropical dry-forest trees: individualistic responses to climatic variation, Journal of Tropical Ecology 17 (2001), pp. 41-60.

Ernst et al., 1990 W.H.O. Ernst, J.E. Decelle and D.J. Tolsma, Predispersal seed predation in native leguminous shrubs and trees in savannas of southern Botswana, African Journal of Ecology 28 (1990), pp. 45-54.

Fichtler et al., 2003 E. Fichtler, D.A. Clark and M. Worbes, Age and long-term growth of trees in an old-growth tropical rain forest, based on analyses of tree rings and ${ }^{14} \mathrm{C}$, Biotropica 35 (2003), pp. 306-317. 
Fichtler et al., 2004 E. Fichtler, V. Trouet, H. Beeckman, P. Coppin and M. Worbes, Climatic signals in tree rings of Burkea africana and Pterocarpus angolensis from semiarid forests in Namibia, Trees 18 (2004), pp. 442-452.

Gourlay, 1992 Gourlay, I.D., 1992. Age and growth rate determination of some African Acacia species. M.Sc. Dissertation, University of Oxford, London.

Gourlay, 1995 I.D. Gourlay, Growth ring characteristics of some African Acacia species, Journal of Tropical Ecology 11 (1995), pp. 121-140.

Jeltsch et al., 1996 F. Jeltsch, S.J. Milton, W.R.J. Dean and N. Van Rooyen, Tree spacing and co-existence in semi-arid savannas, Journal of Ecology 84 (1996), pp. 583-595.

Leistner, 1967 O.A. Leistner, The plant ecology of the southern Kalahari, Memoirs of the Botanical Survey of

South Africa 38 (1967), pp. 1-172.

Lilly, 1977 Lilly, M.A., 1977. An assessment of the dendrochronological potential of indigenous tree species in South Africa. Environmental Studies Occasional Paper No. 18, Department of Geography and Environmental Studies, University of Witwatersrand, Johannesburg.

Liversidge, 2001 R. Liversidge, A unique habitat threatened, African Wildlife 55 (2001), pp. 24-25.

Milton and Dean, 1995 S.J. Milton and W.R.J. Dean, How useful is the keystone species concept, and can it be applied to Acacia erioloba in the Kalahari Desert?, Zeitschrift für Ökologie und Naturschutz 4 (1995), pp. 147-156. 
Schoengart et al., 2002 J. Schoengart, M.T.F. Piedade, S. Ludwighausen, V. Horna and M. Worbes, Phenology and stem-growth periodicity of tree species in Amazonian floodplain forests, Journal of Tropical Ecology 18 (2002), pp. 581-597.

Schoengart et al., 2004 J. Schoengart, W.J. Junk, M.T.F. Piedade, J.M. Ayres, A. Huettermann and M. Worbes, Teleconnection between tree growth in the Amazonian floodplains and the El Nino-Southern Oscillation effect, Global Change Biology 10 (2004), pp. 683-692.

Seymour and Milton, 2003 C. Seymour and S. Milton, A collation and overview of research information on Acacia erioloba (Camelthorn) and identification of relevant research gaps to inform protection of the species, Department of Water Affairs and Forestry, Pretoria (2003).

Smit, 1999 N. Smit, Guide to the Acacias of South Africa, Briza, Pretoria (1999).

Stahle et al. 1996 Stahle, D.W., Cleaveland, M.K., Haynes, G.A., Klimowicz, J., Ngwenya, P., Mushove, P., 1996. Preliminary tree-ring investigations of indigenous trees in Zimbabwe. In: Mushove, P.T., Shumba, E.M., Matose, F., (Eds.), Sustainable management of indigenous forests in the dry tropics. Proceedings of an International Conference in Kadoma, Zimbabwe, Zimbabwe Forestry Commission, Harare.

Stahle et al., 1999 D.W. Stahle, P.T. Mushove, M.K. Cleaveland, F. Roig and G.A. Haynes, Management implications of annual growth rings in Pterocarpus angolensis from Zimbabwe, Forest Ecology and Management 124 (1999), pp. 217-229.

Steenkamp et al., 1999 C.J. Steenkamp, M.W. Van Rooyen and N. Van Rooyen, A nondestructive sampling method for dendrochronology in hardwood species, Southern African Forestry Journal 186 (1999), pp. 5-7. 
Stuiver et al., 1998 M. Stuiver, P.J. Reimer, E. Bard, J.W. Beck, G.S. Burr, K.A. Hughen, B. Kromer, G. McCormac, J. Van der Plicht and M. Spurk, INTCAL 98 radiocarbon age calibration, 24,000-0 cal BP, Radiocarbon 40 (1998), pp. 1041-1084.

Theron et al., 1985 Theron, G.K., van Rooyen, N., Van Rooyen, M.W., 1985. Vegetation structure and vitality in the lower Kuiseb. In: Huntley, B.J. (Ed.), The Kuiseb environment: the development of a monitoring baseline. South African Scientific Programmes Report 106, pp. 81-91, Council for Scientific and Industrial Research, Pretoria.

Therrell et al., 2007 M.D. Therrell, D.W. Stahle, M.M. Mukelabai and H.H. Shugart, Age, and radial growth dynamics of Pterocarpus angolensis in southern Africa, Forest and Ecology Management 244 (2007), pp. 24-31.

Timberlake et al., 1999 J.C. Timberlake, C. Fagg and R. Barnes, Field Guide to the Acacias of Zimbabwe, CBC Publishing, Harare (1999).

Trouet et al., 2001 V. Trouet, K. Haneca, P. Coppin and H. Beeckman, Tree ring analysis of Brachystegia spiciformis and Isoberlinia tomentosa: evaluation of the ENSO-signal, in the miombo woodland of eastern Africa, IAWA Journal 22 (2001), pp. 385-399.

Van Rooyen and Van Rooyen, 1998 N. Van Rooyen and M.W. Van Rooyen, Vegetation of the South-western arid Kalahari: an overview, Transactions of the Royal Society of South Africa 53 (1998), pp. 113-140.

Van Rooyen et al., 1984 N. Van Rooyen, D.J. Van Rensburg, G.K. Theron and J.du P. Bothma, A preliminary report on the dynamics of the vegetation of the Kalahari Gemsbok National Park, Koedoe (Suppl) 27 (1984), pp. 83-102. 
Van Rooyen et al., 1990 N. Van Rooyen, D. Bezuidenhout, G.K. Theron and J.du P. Bothma, Monitoring of the vegetation around artificial water points (windmills) in the Kalahari Gemsbok National Park, Koedoe 33 (1990), pp. 63-87.

Van Rooyen et al., 1996 Van Rooyen, N., Theron, G.K., Bredenkamp, G.J., Van Rooyen M.W., Deutschländer, M., Steyn, H.M., 1996. Phytosociology, vegetation dynamics and conservation of the southern Kalahari. Unpublished Report on a project executed on behalf of the Department of Environmental Affairs and Tourism, University of Pretoria, Pretoria.

Vogel, 1971 J.C. Vogel, Radiocarbon in Nature, South African Journal of Science 67 (1971), pp. 32-42.

Vogel, 2000 J.C. Vogel, Radiocarbon dating of the Iron Age sequence in the Limpopo valley, South African Archaeological Society Goodwin Series 8 (2000), pp. 51-57.

Vogel and Fuls, 2005 J.C. Vogel and A. Fuls, The life-span of leadwood trees, South African Journal of Science 101 (2005), pp. 98-100.

Vogel et al., 1986 J.C. Vogel, A. Fuls, E. Visser and B. Becker, Radiocarbon fluctuations during the third millenium BC, Radiocarbon 28 (1986), pp. 935-938.

Vogel et al., 1993 J.C. Vogel, A. Fuls, E. Visser and B. Becker, Pretoria calibration curve for short-lived samples, 1930-3350 BC, Radiocarbon 35 (1993), pp. 73-85.

Vogel et al., 2001 J.C. Vogel, A. Fuls and E. Visser, Radiocarbon adjustment to the dendrochronology of a yellowwood tree, South African Journal of Science 97 (2001), pp. $164-166$.

Vogel et al., 2002 J.C. Vogel, A. Fuls and E. Visser, Accurate dating with radiocarbon from the atom bomb tests, South African Journal of Science 98 (2002), pp. 457-458. 
Ward and Breen, 1983 T.D. Ward and C.M. Breen, Drought stress and the demise of Acacia albida along the lower Kuiseb River, central Namib Desert: preliminary findings, South African Journal of Science 79 (1983), pp. 444-447.

Weather Bureau, 1998 Weather Bureau, Climate of South Africa. Climate statistics, (Electronic database) Department of Environmental Affairs and Tourism, Pretoria (1998).

Worbes, 1995 M. Worbes, How to measure growth dynamics in tropical trees, a review, IAWA Journal 16 (1995), pp. 337-351.

Worbes, 1999 M. Worbes, Annual growth rings, rainfall-dependent growth and long-term growth patterns of tropical trees from the Caparo Forest Reserve in Venezuela, Journal of Ecology 87 (1999), pp. 391-403.

Worbes, $2002 \mathrm{M}$. Worbes, One hundred years of tree-ring research in the tropics - a brief history and an outlook to future challenges, Dendrochronologia 200 (2002), pp. 217-231.

Worbes and Junk, 1989 M. Worbes and W.J. Junk, Dating tropical trees by means of ${ }^{14} \mathrm{C}$ from bomb tests, Ecology 70 (1989), pp. 503-507.

Worbes et al., 2003 M. Worbes, R. Staschel, A. Roloff and W.J. Junk, Tree ring analysis reveals age structure, dynamics and wood production of a natural forest stand in Cameroon, Forest and Ecology Management 173 (2003), pp. 105-123.

Corresponding author. Tel.: +27 12420 2009; fax: +27 123625099 .

1 Current address: Department of Land Management, Polytechnic of Namibia, Windhoek, Namibia. 